\title{
The Emerging Challenges for Online Teaching in the Times of COVID-19: An Emerging Market Perspective
}

\author{
Sumayya A. Banna
}

\begin{abstract}
Before the coronavirus disease 2019 (COVID-19) crisis, most academic institutions, i.e., schools, colleges, and universities in Kuwait utilized face-to-face settings, and hence, were based on only traditional methods of learning. Although many academic institutions have started employing blended learning, several institutions continue to stick with conventional procedures. The sudden outbreak of the COVID-19 crisis has shaken the educational sector in Kuwait, and the Middle East and North Africa region by forcing instructors to shift to the online mode of teaching overnight to maintain their status. Many instructors hesitant of readjusting their conventional pedagogical approach have had no option except shifting solely to an online teaching environment. Consequently, the purpose of this study is to shed light on the challenges and highlight the success factors of e-learning and the online teaching approach during the COVID-19 crisis. This study also proposes some useful suggestions for professionals in higher education institutions, i.e., senior managers, leaders, and others, on dealing with the challenges associated with the online paradigm in the post-COVID-19 crisis time-period.
\end{abstract}

Index Terms-COVID-19, e-learning, online teaching, challenges and success factors.

\section{INTRODUCTION}

E-learning or online education is an electronic system through which education can be imparted via the internet. The key objective of the e-learning system is to provide education in situations where students and instructors are separated by time and/or distance [1]. Since the e-learning system enables students to learn and complete their courses without physically attending courses in an on-campus setting, it was deemed as the only solution during the coronavirus disease 2019 (COVID-19) crisis as a preventive precaution. During the lockdown imposed due to COVID-19, all academic institutions, including schools, universities, and colleges, were closed in Kuwait by the end of February 2020 Consequently, university leaders, faculty members/instructors, and administrators faced significant challenges in adapting to online teaching, maintaining the minimum communication with students, and supporting the learning process. The preparations to utilize e-learning were initiated after the universities decided to suspend on-campus lectures, which challenged the faculty members to prepare virtual lectures in a short period of time for some universities in Kuwait. The transition to online learning was certainly a

Manuscript received July 17, 2021; revised September 18, 2021.

The author is with the Arab Open University, Kuwait Branch, Kuwait (e-mail: sumayya@aou.edu.kw). challenge for many academic institutions in Kuwait because of the deficiency in utilizing e-learning, as reflected in its low adoption rate, low quality, and the style of pedagogy, before COVID-19. This deficiency was the result of universities preferring traditional lectures over online courses, due to which there were limited online classes offered before COVID-19, and the implementation of the online paradigm remained restricted.

In this regard, the extent to which faculty members have successfully mastered the challenges and relevant success factors of e-learning remains unknown. The extensive closure of educational institutions required rapid transformation in technological innovations and digitalization in the educational context [2]. Indeed, digitalization in educational institutions has been prominent even before the start of the COVID-19 crisis. However, universities in Kuwait have lagged behind in terms of information and communication technologies (ICT) transformation. This requires an exploration of the challenges being faced by faculty members as well as their satisfaction with the online teaching environment. The present study surveyed faculty members of five universities in Kuwait as a target group as instructors were expected to outline the challenges of online teaching in the current situation appropriately; these members were selected regardless of whether they belonged to the "digital native" generation. The study aims were:

1) To explore the impediments to online teaching during COVID-19 among higher educational institutions in Kuwait.

2) To provide recommendations for the success of online learning during COVID-19 and post-COVID-19.

\section{LITERATURE REVIEW}

The growing popularity of ICT in various economic sectors has been beneficial for different industries. The use of ICT has also increased in the educational sector globally [3], [4]. The growing popularity of e-learning has offered the sector economic advantages such as lowered costs of the scarce resources of textbooks, building, space, capacity, etc. Additionally, e-learning in terms of distance learning and education has provided students with easier communication, accessibility, and convenience than that available in traditional education settings. Additionally, the rising pressure to acquire education at convenient times due to the busy work and life schedules, and commitments of working learners and students makes online education an attractive option for them [5]. Therefore, online teaching and e-learning have become popular among US colleges in the 
last decade [6]-[9]. However, academic institutions in Kuwait have not matched up with universities in the US and other Western countries as online teaching is still in its infancy in Kuwait. Indeed, e-learning has enabled universities in the US to expand their current geographic reach and be recognized globally as educational providers even before COVID-19. The online teaching phenomena has been a part of mainstream teaching in Western universities long before COVID-19 [10]. Hence, the transition from the traditional lecture setting to online teaching was a much smoother process for such universities as compared to universities in the Middle East and North Africa region, where there are low adoption rates of online teaching, and limited capacities in terms of information and technology infrastructure and other enablers of e-learning.

Faculty members in higher education institutes have increasingly been asked to conduct lectures and teach online [11]; however, they still remain reluctant to embrace different forms of teaching due to increased workload, fear of new technology, reliability of technology, and skepticism about student learning objectives and outcomes in the online learning environment [1], [12]-[14]. Consequently, fostering the faculty's perceptions of online teaching challenges is critical for the strategic plan of higher academic institutions. To accomplish this objective, it is important for administrators to understand how faculty perceive the challenges presented by online teaching and what factors shape the success of online delivery methods.

The existing literature expands on the role of instructors in the online teaching environment and whether this role is similar or different than instructors' role in conventional settings. For instance, Easton (2003) emphasized the importance of student-instructor interactions and concluded that online teaching elevated the workload of academic instructors, making it more labor intensive than traditional teaching [15]. Easton's study suggested that it is important to clarify the roles of instructors in the online teaching environment by focusing on communication skills for effective virtual teaching. Another study compared the attitudes of non-business instructors and students at several academic institutions [16]. The results revealed that instructors were willing to teach online courses again in the future and students were satisfied with the online teaching experience, but the quality of online teaching was lower than that in traditional classroom settings. Furthermore, the interactions between instructors and students played no defining role in the students' satisfaction experiences [16]. Similarly, Ryan, Hodson, and Nagia (2004) suggested that support systems, technology partnerships, and policies should be in place before redesigning online nursing education courses [17]. For redesigning online courses, the strategies of collaboration, rethinking communication, and faculty development and training should be used. Their study further showed that redesigning and rethinking faculty roles emerged as the number one priority area to address in the online teaching context. It also indicated that faculty members who had taught online before were more satisfied and competent in online contexts compared with those who had never taught online before [17].

A strand of literature supports the importance of online teaching and the e-learning context for the future as they provide wider learning opportunities than the traditional teaching context [18]. Advantages in the online environment can be gained by providing an adequate infrastructure that is vital to support active participation among instructors and students, which would then lead to a sense of ownership [19]. An earlier study indicated government support as a key driver for the promotion of e-learning in higher education institutions in Saudi Arabia [20]. Many studies have also emphasized faculty perceptions of e-learning in higher education institutions [19], [21]-[23]. A study reviewed the challenges faced by instructors when developing online learning programs and found inadequate technical skills, time limitations, poor infrastructure, lack of organizational strategy and support, and negative attitude to be the major challenges [3]. To the best of my knowledge, only limited studies have emphasized the emerging challenges of the online learning paradigm during the COVID-19 crisis, and provided recommendations for the success of online learning in the post-COVID-19 time-period.

\section{METHODS}

The purpose of the present research was to determine the perceptions of faculty members about online teaching in terms of its challenges and success factors during the COVID-19 crisis. Therefore, the data collection process started at the end of February 2020 when academic institutions were completely closed in Kuwait and was completed in March 2021. The survey consisted of two parts. Part one of the survey contained questions to obtain the demographic information of the respondents such as their age, gender, rank, and years of teaching experience (online and offline). Part two of the survey comprised 21 Likert-type questions concerning impediments to online teaching. A total of 84 completed surveys were received which made-up more than $17 \%$ of the acceptable response rate for online surveys [24]. Half of the respondents were fully employed in non-profit and public higher educational institutions in Kuwait, whereas the remaining half worked in small private higher academic institutions.

\section{FINDINGS AND DISCUSSION}

Table I presents the demographic characteristics of the respondents. Nearly three-fourths of the respondents were males, and slightly less than $25 \%$ held an academic rank of associate or full professor. All respondents were full-time employees, and $90 \%$ had 10 or more years of college teaching experience.

When asked whether they had taught an online course before, slightly more than $65 \%$ of the respondents answered affirmatively. Of this group, the top two disciplines that had been taught online by the respondents were business administration (49\%) and marketing (13\%); however, only $4 \%$ and $5 \%$ had taught accounting and finance online, respectively. This suggests that offering online courses in the business field is extremely demanding during COVID-19 times. 
TABLE I: PARTICIPANTS' DEMOGRAPHIC PROFILE

\begin{tabular}{ll}
\hline \multicolumn{2}{c}{ TABLE I: PARTICIPANTS ${ }^{\prime}$ DEMOGRAPHIC PROFILE } \\
\hline \hline Participants' Profile & Percentage (\%) \\
\hline \hline Gender & $27 \%$ \\
Female & $73 \%$ \\
Male & \\
\hline Age Group & $3 \%$ \\
25-34 years & $41 \%$ \\
35-44 years & $32 \%$ \\
45-54 years & $18 \%$ \\
55-64 years & $6 \%$ \\
65 years and above & \\
\hline Academic Rank & $38 \%$ \\
Instructor & $38 \%$ \\
Assistant Professor & $18 \%$ \\
Associate Professor & $6 \%$ \\
Full Professor & \\
\hline Years of Traditional Teaching Experience & $10 \%$ \\
Below 10 years & $90 \%$ \\
10 years and above & \\
\hline Have you taught an online course before? & $65 \%$ \\
Yes & $35 \%$ \\
No & \\
\hline If yes, which discipline have you taught online? & $49 \%$ \\
Business Administration & $10 \%$ \\
Management & $4 \%$ \\
Accounting & $2 \%$ \\
Computer Science & $13 \%$ \\
Human Resource Management & $6 \%$ \\
Marketing & $5 \%$ \\
Economics & $3 \%$ \\
Finance & \\
Information Systems & \\
\hline & \\
\hline
\end{tabular}

Table II presents the respondents' answers to the 21 Likert-type questions on the impediment to online teaching. These questions have been rearranged into similar groups by five different categories. Specifically: statements 3, 4, 5, 6, 7, and 8 are concerned with technology-related problems; statements 1 and 2 focus on interaction and learning problems; statements $14,15,16$, and 17 focus on course management and autonomy problems; statements 18, 19, 20, and 21 deal with appreciation of online teaching performance; and statements $9,10,11,12$, and 13 focus on regulation and control problems. Tables III and IV display the mean, standard deviation, and significance level for each statement.

Statements 1 and 2 in Table II deal with perspectives on instructor-student interactions and learning experience. The major challenge faced by the respondents during online teaching was the lack of social interaction with students. Importantly, $21 \%$ of respondents felt that online learning hinders social interactions and personal relationships, thereby affecting the students' learning experiences. This result is supported by previous studies [15], [16].

Statements 14, 15, 16, and 17 address problems related to autonomy and course management. Interestingly, a majority of the respondents felt that online teaching requires more time commitment, and half of the respondents also felt that course content autonomy, involvement, and decision-making are lagging in online teaching. Additionally, nearly $50 \%$ of respondents agreed that online teaching formats demand more time for grading and feedback. This may be due to the more frequent interactions with students and more individualized service features of online courses. Another contributing factor could be the substantial student enrolments in certain sections, leading to a bigger class size; this trend is common among large educational institutions in
Kuwait.

TABLE II: PARTICIPANT RESPONSES ABOUT IMPEDIMENTS TO ONLINE TEACHING

\begin{tabular}{llcccc}
\hline \hline Statement & $\begin{array}{c}\text { Strongly } \\
\text { Disagree }\end{array}$ & Disagree & $\begin{array}{c}\text { Agree } \\
\text { nor } \\
\text { Disagree }\end{array}$ & Agree & $\begin{array}{c}\text { Strongly } \\
\text { Agree }\end{array}$ \\
\hline \hline
\end{tabular}

Instructor-Student Interaction

1. Lack of

personal

$\begin{array}{lllll}\text { relationship with } & 44 \% & 32 \% & 15 \% & 5 \%\end{array}$

students

2. Lack of social

interaction within

$46 \%$

$9 \%$

$6 \%$ the class

Technology-related Problems

3. Inadequate

technology

support

4. Inadequate

instructor training

5. Frequent

technology

failures

$6 \%$

$6 \% \quad 21 \%$

$27 \%$

$32 \%$

$15 \%$

6. Rapidly

changing

software or

$$
9 \%
$$

$15 \%$

$29 \%$

$24 \%$

$24 \%$

delivery systems

7. Lack of fast

access for users

8. Personal

anxiety/fear

regarding

technology/online

teaching

Regulation and Control Problems

\begin{tabular}{|c|c|c|c|c|c|}
\hline $\begin{array}{l}\text { 9. Lack of } \\
\text { enrollment limits }\end{array}$ & $21 \%$ & $3 \%$ & $41 \%$ & $27 \%$ & $9 \%$ \\
\hline $\begin{array}{l}\text { 10. Lack of } \\
\text { control over } \\
\text { student cheating } \\
\text { 11. Misalignment } \\
\text { with }\end{array}$ & $9 \%$ & $6 \%$ & $21 \%$ & $32 \%$ & $32 \%$ \\
\hline $\begin{array}{l}\text { accreditations and } \\
\text { ministry } \\
\text { requirements }\end{array}$ & $14 \%$ & $9 \%$ & $24 \%$ & $41 \%$ & $12 \%$ \\
\hline $\begin{array}{l}\text { 12. Lack of } \\
\text { policies or } \\
\text { standards for } \\
\text { online courses }\end{array}$ & $6 \%$ & $12 \%$ & $24 \%$ & $38 \%$ & $21 \%$ \\
\hline $\begin{array}{l}\text { 13. Lack of } \\
\text { control over } \\
\text { property rights }\end{array}$ & $12 \%$ & $12 \%$ & $24 \%$ & $44 \%$ & $9 \%$ \\
\hline
\end{tabular}

\section{Course Management Problems}

14. Lack of

autonomy over

$9 \%$

$12 \%$

$29 \%$

$44 \%$

$6 \%$

15. Lack of

faculty

involvement in

course

decision-making

16. Time

commitment

17. Inadequate

time for grading

and feedback

Performance Appraisal and Appreciation Problems

18. Increased

workload

19.Lack of focus

on research

$9 \%$

$15 \%$

$24 \%$

$27 \%$

$27 \%$

activities/projects

20. Online work

not valued for

promotion and 
tenure

21. Inadequate

compensation for

$9 \%$

$15 \%$

$38 \%$

$29 \%$

$9 \%$

*1= Strongly Disagree; $2=$ Disagree; $3=$ Neither Agree nor Disagree; 4= Agree; 5= Strongly Agree.

Statements 18, 19, 20, and 21 address online teaching performance appreciation. The majority of the respondents agreed that online teaching mandates time commitment and increases the workload due to various reasons, such as the additional time required for grading and feedback, as indicated earlier. Additionally, 38\% of the respondents felt that online teaching was inadequately compensated and appreciated. Half of the respondents were indifferent regarding this issue. Furthermore, almost $55 \%$ of the respondents agreed that an insufficient amount of time is committed to research, which may have affected their performance appraisal.

Statements 9, 10, 11, 12, and 13 address problems related to regulations, standards, and control. While $65 \%$ of the respondents felt that there is a lack of control over cheating by students in the e-learning system, $59 \%$ of the respondents agreed that there is a lack of standards and policies for online modules. The student cheating, statement 10, could be common for quantitative courses such as statistics, math, and accounting. To overcome student cheating, it is important for university administrations to strengthen academic integrity policies and apply strict standards to ensure that good-quality online learning is delivered. Slightly more than $50 \%$ of respondents opined that e-learning was not implemented earlier because online courses have not been accepted and accredited by the Ministry of Higher Education in Kuwait. This fact has been invalidated during the COVID-19 era as it has become mandatory to proceed with online education. Additionally, $53 \%$ of the respondents agreed that one of the impediments to online teaching is the lack of control over property rights.

Regarding faculty perception about problems related to training and technology (statements 3, 4, 5, 6, 7, and 8), slightly less than $50 \%$ of the respondents believed that instructors need training for online courses, and there is insufficient IT support for e-learning modules from their academic institutions. Almost $44 \%$ of the respondents agreed that they have faced frequent technology failures, which have hindered students' fast access to online courses. Although $35 \%$ of the respondents faced rapidly changing software at their institutions, this may be due to prolonged demands to improve online teaching using a better delivery system. For example, at the start of the COVID-19 lockdown, some universities in Kuwait moved to Moodle as an e-learning platform, and later shifted to Microsoft Teams for a better delivery system. Only a few respondents agreed to experiencing anxiety and fear regarding online teaching platforms. The more the universities implement online courses, the more likely are the faculty members to overcome these psychological problems. As shown in Table III, the means range from 1.05 to 2.95 for the respondents who taught online courses. An examination of each of the five categories reveals that the highest mean is for the category of course management problems $(M=2.99, S D=0.78)$, followed by technology-related problems $(M=2.95, S D=$ $1.03)$, regulation and control problems $(M=2.90, S D=1.04)$, performance appraisal and appreciation problems $(M=2.89$, $S D=0.85)$, and instructor-student interaction problems $(M=$ $1.05, S D=0.94)$. This indicates that faculty members' overall perceptions ranged from agreement to approaching strong agreement for e-learning in higher education in Kuwait.

As shown in Table IV, the means range from 1.14 to 2.23 for the respondents who did not teach online courses. An examination of the five categories reveals that the highest mean is for the category of technology-related problems $(M=$ 2.33, $S D=0.82)$, followed by regulation and control problems $(M=2.25, S D=0.85)$, performance appraisal and appreciation problems $(M=1.88, S D=0.87)$, course management problems $(M=1.74, S D=0.88)$, and instructor-student interaction problems $(M=1.14, S D=0.93)$. This indicates that faculty members have recognized challenges relating to technology, control, performance appraisal, and communication in e-learning implementation in higher education in Kuwait during COVID-19.

TABLE III: MEANS AND STANDARD DEVIATIONS FOR EACH SURVEY STATEMENT FOR RESPONDENTS WHO TAUGHT ONLINE (N=55)

\begin{tabular}{|c|c|c|}
\hline Statement & Mean & SD \\
\hline Instructor-Student Interaction & 1.44 & 1.02 \\
\hline 1. Lack of personal relationship with students & 1.5 & 1.68 \\
\hline 2. Lack of social interaction within the class & 1.56 & 1.18 \\
\hline Technology-related Problems & 1.62 & 1.26 \\
\hline 3.Inadequate technology support & 1.1 & 1.34 \\
\hline 4. Inadequate instructor training & $1.74 * *$ & 1.42 \\
\hline 5. Frequent technology failures & 1.8 & 1.5 \\
\hline $\begin{array}{l}\text { 6. Rapidly changing software or delivery } \\
\text { systems }\end{array}$ & $1.86^{*}$ & 1.58 \\
\hline 7. Lack of fast access for users & 1.92 & 1.66 \\
\hline $\begin{array}{l}\text { 8. Personal anxiety/fear regarding } \\
\text { technology/online teaching }\end{array}$ & $1.98 * *$ & 1.74 \\
\hline Regulation and Control Problems & 2.04 & 1.82 \\
\hline 9. Lack of enrollment limits & $1.82 * *$ & 1.9 \\
\hline 10. Lack of control over student cheating & $1.46^{* *}$ & 1.98 \\
\hline $\begin{array}{l}\text { 11. Misalignment with accreditations and } \\
\text { ministry requirements }\end{array}$ & $2.22 *$ & 1.06 \\
\hline $\begin{array}{l}\text { 12. Lack of policies or standards for online } \\
\text { courses }\end{array}$ & $1.49 *$ & 1.14 \\
\hline 13. Lack of control over property rights & 2.34 & 0.99 \\
\hline Course Management Problems & 3.33 & 1.98 \\
\hline 14. Lack of autonomy over course content & 2.46 & 1.38 \\
\hline $\begin{array}{l}\text { 15. Lack of faculty involvement in course } \\
\text { decision-making }\end{array}$ & 1.59 & 1.06 \\
\hline 16. Time commitment & $2.54^{*}$ & 1.33 \\
\hline 17. Inadequate time for grading and feedback & $2.58 *$ & 1.03 \\
\hline $\begin{array}{l}\text { Performance Appraisal and Appreciation } \\
\text { Problems }\end{array}$ & 2.54 & 1.33 \\
\hline 18. Increased workload & $4.46^{*}$ & 0.86 \\
\hline 19. Lack of focus on research activities/projects & 3.89 & 0.78 \\
\hline $\begin{array}{l}\text { 20. Online work not valued for promotion and } \\
\text { tenure }\end{array}$ & $1.86^{*}$ & 0.97 \\
\hline 21. Inadequate compensation for instruction & 1.34 & 0.79 \\
\hline
\end{tabular}

Table $\mathrm{V}$ presents the results for the closed ended questions asked in the survey to measure the level of satisfaction with online teaching among instructors in Kuwait. Interestingly, almost $65 \%$ would teach online courses in the future, and are satisfied with online teaching despite the challenges faced by them in the online environment. It is worth noting that the percentage of respondents answering in the affirmative to the two closed-ended questions is similar to the percentage of 
respondents who have taught online courses before (Table I). This indicates that faculty members who had taught online classes before were slightly more satisfied with the online environment compared with those who had not taught online classes before, possibly because the former would have mastered the technical skills and gained the experience required for the online context. This finding is confirmed by a past study [17].

TABLE IV: MEANS AND STANDARD DEVIATIONS FOR EACH SURVEY STATEMENT FOR RESPONDENTS WHO DID NOT TEACH ONLINE $(N=29)$

\begin{tabular}{|c|c|c|}
\hline Statement & Mean & SD \\
\hline Instructor-Student Interaction & $\mathbf{1 . 1 4 5}$ & 0.93 \\
\hline 1.Lack of personal relationship with students & 1.3 & 0.98 \\
\hline 2. Lack of social interaction within the class & 0.99 & 0.88 \\
\hline Technology-related Problems & 2.33 & 0.82 \\
\hline 3.Inadequate technology support & 1.98 & 0.74 \\
\hline 4. Inadequate instructor training & 1.92 & 0.66 \\
\hline 5. Frequent technology failures & 3.22 & 0.82 \\
\hline 6. Rapidly changing software or delivery systems & 1.82 & 0.99 \\
\hline 7. Lack of fast access for users & 1.44 & 0.87 \\
\hline $\begin{array}{l}\text { 8. Personal anxiety/fear regarding technology/online } \\
\text { teaching }\end{array}$ & 3.58 & 0.83 \\
\hline Regulation and Control Problems & 2.25 & 0.85 \\
\hline 9. Lack of enrollment limits & $2.46^{*}$ & 0.82 \\
\hline 10. Lack of control over student cheating & $2.66^{*}$ & 0.74 \\
\hline $\begin{array}{l}\text { 11. Misalignment with accreditations and ministry } \\
\text { requirements }\end{array}$ & $3.23 *$ & 0.96 \\
\hline 12. Lack of policies or standards for online courses & 1.1 & 0.95 \\
\hline 13. Lack of control over property rights & 1.8 & 0.78 \\
\hline Course Management Problems & $\mathbf{1 . 7 3 7 5}$ & 0.88 \\
\hline 14. Lack of autonomy over course content & 1.5 & 1.68 \\
\hline $\begin{array}{l}\text { 15. Lack of faculty involvement in course } \\
\text { decision-making }\end{array}$ & $1.74 *$ & 0.59 \\
\hline 16. Time commitment & $2.22 *$ & 0.56 \\
\hline 17. Inadequate time for grading and feedback & $1.49 *$ & 0.69 \\
\hline $\begin{array}{l}\text { Performance Appraisal and Appreciation } \\
\text { Problems }\end{array}$ & 1.8875 & $\begin{array}{c}0.872 \\
5\end{array}$ \\
\hline 18. Increased workload & $1.46^{*}$ & 0.77 \\
\hline 19. Lack of focus on research activities/projects & 1.89 & 0.88 \\
\hline 20. Online work not valued for promotion and tenure & 1.86 & 0.85 \\
\hline 21. Inadequate compensation for instruction & 2.34 & 0.99 \\
\hline \multicolumn{3}{|c|}{ SD = standard deviation, $* p<0.05 ; * * p<0.01 ; * * * p<0.001}$. \\
\hline \multicolumn{3}{|c|}{ TABLE V: SATISFACTION OF RESPONDENTS WITH ONLINE TEACHING } \\
\hline Statement & & No \\
\hline $\begin{array}{l}\text { Would you prefer to teach online courses } \\
\text { in the future? }\end{array}$ & & $35 \%$ \\
\hline Are you satisfied with online teaching? & & $33 \%$ \\
\hline
\end{tabular}

\section{RECOMMENDATIONS FOR ENSURING THE SUCCESS OF ONLINE LEARNING}

The COVID-19 pandemic forced educational institutions worldwide to shift rapidly to distance and online learning as a solution for their sustainability. The pandemic also forced universities in Kuwait to declare a state of emergency and explore the available options to adopt online learning systems. Consequently, the accessibility to and implementation of online learning materials in the e-learning system became the main challenge for many universities during the COVID-19 pandemic in Kuwait. There were also a few academic institutions that did not experience as much difficulty as they naturally proceeded to use the available ways of learning such as e-learning systems.

The e-learning platform is not new. This open learning system is mainly based on a blended education approach with quality standards that revolves around the idea of tutored independent learning. The e-learning system has a significant source of information, due to its ubiquity (availability anywhere and anytime), low cost, ease of use, and interactive features and functions. It has offered academic institutions several advantages and useful features that could be employed for use during the crisis too. Through the e-learning system, students can engage in learning activities with instructors on a laptop or mobile device from their home or anywhere else.

The key success factors for the online teaching environment can be attained by overcoming the challenges and problems faced by academic instructors and faculty members in Kuwait, who had to rapidly learn and practice online learning tools and software; things could have been different if they had already mastered it. The time lost in learning the tools and technology could have been spent on creating more valuable content for online courses. However, it is better late than never. A key argument here is to close the gap between students' conventional learning and development, and the experience and skills required to enter the information economy, i.e., the online paradigm [25]. The need to prepare students for using technological skills and digital resources right from primary school is well acknowledged in Kuwait. Although adequate technical infrastructure and ICT implementation are required to create an effective instructional context, instructors and students must also be encouraged to apply digital tools. It must also be noted that increasing digital literacy competence among instructors cannot be ensured without adequate training. Hence, it is vital to integrate ICT tools with learning objectives and outcomes in a way to be better prepared for digitalization in academic institutions and remain open.

One factor to ensure the success of online teaching is to resolve technology-related problems by providing regular and intensive training sessions for all late adopters of technology; these sessions could be formal or informal. The information and technology infrastructure has to be utilized to its fullest in higher academic institutions. Hence, senior management should invest substantially in technology infrastructure as the main driver of financial value generation and sustainer of market equity in the future. The results of this study suggest that the online teaching environment should be sustained in the future because it is the best way to enhance student-instructor interactions. This should be viewed as a lesson learned from the experienced US universities that have an extensive online teaching and distance learning system in place regardless of any global crisis. In this regard, it has been found that the online teaching paradigm offers no significant face-to-face contact, and no context clues for immediate communication in the first few weeks of the semester, due to which students usually feel anxious about what is expected from them; however, real learning can be effectively achieved when both students and instructors start feeling comfortable in the new online environment [4]. This eventually leads to different stakeholders' satisfaction, adding value to higher educational institutions. The current study's results suggest that it is essential for higher education institutions to redesign roles, policies, and standards that suit the online paradigm, and not leave this task up to individuals [4], [17]. 
The key lesson is to embrace e-learning technology before disaster strikes [26]. Initially, for the higher academic institutions, the online environment can be costly and time consuming. For the instructor, the first crucial step is to redesign new types of assessments to better suit the online paradigm. It is also important to ensure that there is a gradual transformation of traditional education techniques to the new online methodology, rather than a sudden shift and transfer from the former to the latter [4]. We need to be proactive and prepared to adapt to any sudden changes or re-adjust to online delivery modes in times of situations such as the COVID-19 pandemic. Accordingly, higher academic institutions and organizations should prepare contingency plans to deal with challenges such as natural disasters [27].

Academic institutions in Kuwait should recognize the importance of e-learning and invest substantially to possess effective and reliable information, and technical capacities and infrastructure; this will enable these institutions to provide a one-stop shop portal for the instructors and students to utilize the online educational environment [28], [29]. Moreover, senior management and leadership in Kuwait must support and smoothen the process of transforming higher educational institutions, which is crucial for their survival. Specifically, senior managers must articulate a strong and clear vision for the stakeholders of academic institutions to accomplish and move forward. Institutional leaders should also readjust and realign their organizational objectives to meet the needs and demands of e-learners [7]. The COVID-19 crisis has taught the higher educational institutions in Kuwait vital lessons about the best practices and most important priorities to respond to and meet the urgent demand of any pandemic or crisis in the future. Indeed, the time is ripe for all of us to reimagine the future we want to live and work in, and start building it. The only way to make a difference in the post-COVID-19 world is to learn to collaborate and cooperate across higher academic institutions and spatial boundaries.

\section{LIMITATIONS AND RECOMMENDATIONS FOR FUTURE STUDIES}

Despite its promising findings, the study had a few limitations. First, the study results cannot be generalized as they reflect the responses of a relatively small sample. Second, none of the respondents had taught online courses in quantitative subjects such as production management and statistics or other non-business-related courses such as nursing, medicine, and science, which may allude to the difficulties associated with offering courses in an online environment. It is important to investigate this issue further among higher education institutions in Kuwait. Additionally, it is important to empirically investigate the perceptions and acceptance levels of e-learning among the faculty and students. Future studies can look at investigating the following research questions:

1) The faculty acceptance or resistance of digital education as one of the main barriers to any change management strategy is the lack of management of human acceptance or resistance of that change.

2) How the universities' ICT tools stimulate instructors' professional competencies with technological pedagogical knowledge and develop their digital skills to help them successfully master challenges related to online teaching.

3) The extent to which faculty members/instructors have mastered the core challenges of the teaching delivery process, such as lecturing, providing feedback, and conducting online assessments, through an online environment.

4) The relationship between previous online teaching experience and satisfaction levels among faculty members.

5) How the extrinsic and intrinsic reward systems can play an important role in providing incentives for university faculty to teach (or continue teaching) online courses.

6) Measures to enhance the level of student engagement in an e-learning system.

\section{CONCLUSION}

The study aimed to explore the online teaching challenges during COVID-19 and provide recommendations to the management and leaders of higher education institutions for the post-COVID-19 crisis time-period. The study revealed that the major challenges encountered by instructors in online teaching were mostly information and technology-related problems, followed by regulation and control problems (policies and standards), and course management problems. The results of this study also suggest that the offering of online courses and teaching is still at an early stage, despite a majority of the respondents indicating their willingness to continue teaching online courses in the future because of their satisfaction with online teaching as early adopters of technology. Therefore, educational institutions must invest substantially in the online teaching paradigm and build resilience in their online teaching systems to ensure their sustainability. It is recommended that further research be undertaken to better understand the online teaching phenomena.

\section{CONFLICT OF INTEREST}

The author declares no conflict of interest.

\section{REFERENCES}

[1] D. Bolliger and O. Wasilik, "Factors influencing faculty satisfaction with online teaching and learning in higher education," Distance Educ. vol. 30, no. 1, pp. 103-116, 2009.

[2] A. E. McFarlane, "Devices and desires: Competing visions of a good education in the digital age," Br. J. Educ. Technol., vol. 50, no. 3, pp. 1125-1136, 2019.

[3] D. O'Doherty, M. Dromey, J. Lougheed, A. Hannigan, J. Last, and D. McGrath, "Barriers and solutions to online learning in medical education - An integrative review," BMC Med. Educ., vol. 18, 130, 2018

[4] M. W. Totaro, J. R. Tanner, T. Noser, J. F. Fitzgerald, and R. Birch, "Faculty perceptions of distance education courses: A survey," J. Coll. Teach. Learn., vol. 2, no. 7, pp. 7-25, July 2011.

[5] B. Roberts, "Training via desktop," HR Magazine, vol. 43, no. 9, pp 98-104, 1998.

[6] K. S. Betts, "Online human touch (OHT) instruction and programming: A conceptual framework to increase online student engagement and retention in online education: Part 1," J. Online Learn. Teach., vol. 4 no. 3, pp. 399-418, Sep. 2008. 
[7] J. Mapuva, "Confronting challenges to e-learning in higher education institutions," Int. J. Educ. Dev. Using Inf. Commun. Technol., vol. 5, no. 3, pp. 101-114, Sep. 2009.

[8] J. D. Mills and D. Raju, "Teaching statistics online: A decade's review of the literature about what works," J. Stat. Educ., vol. 19, no. 2, 2017.

[9] E. Allen and J. Seaman, Staying the Course: Online Education in the United States, Newburyport, MA: The Sloan Consortium, 2008.

[10] N. S. Ali, K. Hodson-Carlton, M. Ryan, J. Flowers, M. A. Rose, and V. Wayda, "Online education: Needs assessment for faculty development," J. Contin. Educ. Nurs., vol. 36, no. 1, pp. 32-38, 2005.

[11] I. E. Allen and J. Seaman, Grade Level: Tracking Online Education in the United States, Babson Park, MA: Babson Survey Research Group and Quahog Research Group, LLC, 2015.

[12] L. Bacow, W. Bowen, K. Guthrie, K. Lack, and M. Long, Barriers to Adoption of Online Learning Systems in U.S. Higher Education, New York, NY: Ithaka, 2012.

[13] K. Betts and A. Heaston, "Build it but will they teach? Strategies for increasing faculty participation and retention in online and blended education," Online J. Distance Learn. Adm., vol. 17, no. 2, 2014.

[14] C. McQuiggan, "Faculty development for online teaching as a catalyst for change," Journal of Asynchronous Learning Networks, vol. 16, no. 2, pp. 27-61, Mar. 2012.

[15] S. Easton, "Clarifying the instructor's role in online distance learning," Commun. Educ., vol. 52, no. 2, pp. 87-105, 2003.

[16] E. Inman, M. Kerwin, and L. Mayes, "Instructor and student attitudes toward distance learning," Community Coll. J. Res. Pract., vol. 23, no. 6, pp. 581-591, 1999

[17] M. Ryan, K. C. Hodson, and A. S Nagia, "Reflection on the role of faculty in distance learning and changing pedagogies," Nurs. Educ. Perspect., vol. 25, no. 2, pp. 73-80, 2004.

[18] C.J. Awalt, "Moving from the classroom to online teaching: A study of change in faculty attitudes," Ph.D. dissertation, Univ. Texas, Austin, TX, 2003.

[19] N.A. Haidar, "Perceptions of higher education online learning faculty in Lebanon," Ph.D. dissertation, Walden Univ., Minneapolis, MN, 2014.

[20] M. Al-Kethery, "Women's colleges in Saudi Arabia apply distance education faculty," Associated with the Canter in Riyadh, vol. 1, pp. 6-23, 2006.

[21] A. Alenezi. "Faculty members' perception of e-learning in higher education in the Kingdom of Saudi Arabia (KSA)," Ed.D. dissertation, Texas Tech Univ., Lubbock, TX, 2012.

[22] K. J. Kim, Y. Kang, and G. Kim, "The gap between medical faculty perceptions and use of e-learning resources," Med. Educ., vol. 22, no. 1, 1338504, 2017.

[23] M. Schulte, "Faculty perceptions of technology distance education transactions: Qualitative outcomes to inform teaching practices," IN Proc. TCC 2010, pp. 77-101, 2010.
[24] P. L. Alreck and R. S. Settle, The Survey Research Handbook, Homewood, IL: Richard D. Irwin, Inc.

[25] R. B. Kozma, "ICT, education transformation, and economic development: An analysis of the US national educational technology plan," E-Learn. Digit. Media, vol. 8, no. 2, pp. 106-120, 2011.

[26] N. Todorova and N. Bjorn-Andersen, "University learning in times of crisis: The role of IT," Account. Educ., vol. 20, no. 6, pp. 597-599, 2011.

[27] E. Seville, C. Hawker, and J. Lyttle, Resilience Tested: A Year and a Half of Ten Thousand Aftershocks, Univ. Canterbury, 2012.

[28] S. Banna. (2020). How AOU to respond to COVID-19 pandemic? AOU Newsletter. [Online]. Available: https://mdl.arabou.edu.kw/kuwait/mod/forum/discuss.php?d=6958

[29] K. A. Meyer and J. L. Wilson, "Online journal of distance learning administration," Univ. West Georgia, Distance Education Center, vol 4, no. 1,2011 .

Copyright (C) 2022 by the authors. This is an open access article distributed under the Creative Commons Attribution License which permits unrestricted use, distribution, and reproduction in any medium, provided the original work is properly cited (CC BY 4.0).

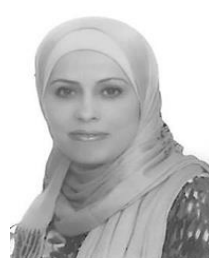

Sumayya A. Banna was born in Amman- Jordan and holds a US citizenship. She completed her Ph.D. in information systems (University of Wollongong, Australia), master's in accounting information and management (University of Texas in Dallas, USA), and bachelor's in business administration (University of Texas in Dallas, USA).

She has more than 20 years of teaching experience and has taught graduate and undergraduate students from a wide variety of backgrounds in Kuwait (American University of Kuwait, Arab Open University), Jordan (Princess Sumaya University for Technology), and Australia (University of Wollongong). She has intensive research experience with a focus on the Middle East. She has mostly delivered courses with a focus on business studies (marketing, management, and Information systems). She has published in international peer reviewed journals ranking $\mathrm{A}, \mathrm{B}$, and $\mathrm{C}$.

Dr. Banna appeared on the Dean's Honor List (2001-2003) of the Faculty of Business and Management of the University of Texas at Dallas, USA Furthermore, she has graduated cum laude (BCs) (UTD-USA, 2001), earned a university postgraduate scholarship (UOW-Australia, 2010), and chaired university committees including the library committee, ICT applications, and professional development. 